\title{
Rubén Darío y sus primeros críticos (1888-1900)
}

\begin{abstract}
Contribuye a iluminar la historia literaria que se ocupa de Rubén Darío y el modernismo una revisión de las ideas expresadas por la crítica en el periodo inicial del poeta centroamericano. Epoca en que éste pugna por imponer - sin ánimo de "formar escuela"- una estética renovadora por la que venían luchando otros primates del modernismo que, después de indagaciones recientes, no pueden designarse como meros precursores:1 Manuel Gutiérrez Nájera, en México; José Martí, en escenario de amplitud continental, gracias a la extensa difusión de su poesía y de sus artículos de índole literaria e ideológica.

Nos ocuparemos en estas páginas, principalmente, de las repercusiones de dos libros iniciales darianos: Azul... y Prosas profanas. Así, limitaremos nuestro campo al periodo I888-r900 y, geográficamente, al ámbito hispanoamericano, pues dichas obras, en sus primeras ediciones, no lograron en la Península el influjo o la difusión de otras posteriores, o el de la segunda edición de Prosas profanas, publicada en París cinco años después de la original. ${ }^{2}$

Podremos observar - de paso- la situación de la estimativa literaria en el siglo xlx, oscilante entre un academicismo acartonado y las efusiones líricas que parafrasean o deterioran los textos comentados. En ese medio crece, a veces con dificultad, la nueva orientación literaria y los signos que la rodean no son, las más de las veces, muy auspiciosos.
\end{abstract}

1. Como síntesis de esta debatida cuestión, es útil la consulta del libro de Ivan A. Schulman, Génesis del modernismo, México: El Colegio de México, 1966.

2 Prosas profanas y otros poemas. París: Librería de la Vda. de C. Bouret, 1901. [160 pp.].

Por impedírnoslo el espacio no hemos tratado en este attículo de otros críticos de Darío que merecen particular consideración. Uno de ellos es don Francisco Gavidia, quien, en 1889, publicó un extenso ensayo en el Repertorio Salvodoreño (t. III, núm. 1, pp. 1-11), que ha reproducido Diego Manuel Sequeira en Rubén Dario criollo en El Salvador. Segunda estada o Atalaya de su revolución poética. León, Nicaragua. Editorial Hospicio, 1965, pp. 24-35. 
Nos apartamos de los dos extremos anotados para elegir sólo a los críticos que se sitúan en un plano proporcionado de aciertos e intenciones. Del mismo modo, dejamos de lado la crítica que podemos denominar "menor", en el sentido de que la constituían gacetillas expresivas de simpatías o diferencias extremadas; éstas, a la distancia, aún dejan correr la bilis de las pequeñas guerras literarias. Ladridos a la luna, son testimonio de la desmesura: oscilan entre el indisimulado rencor o la envidia robadora del sueño. Quede el amargo jardín en su rincón.

Nos referimos, pues, a estudios de mayor alcance y extensión tal, que asegura un considerable esfuerzo de exégesis. Ellos son: I) el prólogo de Eduardo de la Barra en la primera edición de $A z u l$..., reproducido dos años más tarde en la de Guatemala y que es hoy casi desconocido por haberse quitado de las siguientes;32) el estudio de Paul Groussac sobre Prosas profanas que apareció en La Biblioteca, Buenos Aires, I896; 3) el ensayo negador de Manuel Gondra, escrito en I898 como comentario de Prosas profanas y, sobre todo, de sus "Palabras liminares"; $y$, finalmente, cuando el siglo xrx llegaba a su fin, el amplio análisis del mismo libro publicado por José Enrique Rodó en I899 y que dos años más tarde sería el prólogo -anónimo- de la edición aumentada de Prosas profanas. 4

El estudio de Rodó significa la culminación de la crítica novecentista

3 En la edición de Valparaíso (1888), el prólogo de Eduardo de la Barra ocupa las páginas III a XXXIV. En la edición de Guatemala (1890), sigue al estudio de Valera y figura en las páginas XXXV-LXXX; no se anuncia en la portada, en la que se lee: "Segunda edición aumentada / precedida de un estudio sobre la obra / por / don Juan Valera / de la Real Academia Española . Pero en la página XXXV encontramos: "Azul... / por / Rubén Darío. / Prólogo de Eduardo de la Barra". Se reprodujo este prólogo, tan injustamente olvidado, en las Obras escogidas de Rubén Dario publicadas en Cbile, tomo I (único publicado), Santiago, 1939, y, más recientemente, en el Boletín del Instituto de Literatura Cbilena, VI [1967], núms. 13-14, pp. 51-61.

4 Al omitirse el nombre de Rodó como firma de su restudio, publicado en Montevideo (1889) como segundo opúsculo de la serie La vida nueva, se produjo un distanciamiento entre el autor de Ariel y su prologado. Darío achacó el descuido a sus editores; éstos demostraron que el poeta les entregó un ejemplar de la edición de 1889 sin sus tapas, es decir, sin el nombre de Rodó: Emir Rodríguez Monegal, en su cuidadosa edición de las Obras completas de Rodó, Madrid: Aguilar, 1957, detalla este incidente que causó una sostenida posición de desconfianza en Rodó. Su estudio, por lo demás, merecía por parte de Darío la actitud reconocida que éste le negó con su proceder. Según Mario Benedetti, el autor de Ariel se negó a presentar a Darío en Montevideo, en un acto del Teatro Solís (1912), lo que sería una repercusión del distanciamiento posterior a 1901. (Ello, por cierto, no impidió el homenaje de Rodó a Darío cuando éste falleció en 1916). Mario Benedetti, Genio y figura de José Enrique Rodó, Buenos Aires: Eudeba, 1966, p. 44. Ni, por parte de Dario, la dedicatoria del 1 de los Cantos de Vida y Esperanza y el envío de la edición original (1905). ni la coloboración de Rodó en Mundial (diciembre de 1911), ni la "cabeza" de Rodó por Darío (idem, enero de 1912), y del epistolario respectivo. 
frente al modernismo y deja abierta la brecha para la estimativa del siglo xx, en que los libros de Erwin K. Mapes, Arturo Marasso, Pedro Salinas, Erika Lorenz y otros nos aportarán definida luz sobre la poética dariana y lo que significó su contribución al renuevo total de la prosa y la poesía hispánicas.

Pocos exégetas de Darío necesitan más que Eduardo de la Barra de una revaloración justiciera en cuanto a sus aportaciones críticas. La obra de De la Barra sobre el arte naciente del nicaragiiense ocupa una posición cronológica de privilegio y no merece el olvido o desconocimiento que suele rodearla. ${ }^{5}$

La relación personal de ambos - tan significante para Darío en muchos sentidos- empezó muy pocos días después de llegar el escritor a Chile, en 1886, y se extiende por bastantes años, hasta la época en que éste vivía en Buenos Aires y De la Barra estaba en Argentina, en difícil situación de destierro político.

Darío, en el prólogo escrito para Asonantes de Narciso Tondreau, nos dejó una animada evocación del escritor y maestro chileno, de quien recibió, repetidas veces, sólidas muestras de cordialidad y solidaridad literarias. No poca importancia tuvo De la Barra en el ingreso de Darío como redactor de La Nación bonaerense, según puede leerse en la Autobiografia.

Pero, sin duda, lo que mejor une el nombre de Eduardo de la Barra con los comienzos literarios de Rubén Darío es el extenso prólogo que aquél escribió para presentar $A z u l . .$. , estudio hoy preterido a pesar de sus méritos y juicios clarividentes.

Como es bien sabido por los estudiosos de Dario, el poeta, desde su llegada a Chile, publicó con abundancia en los periódicos del país y sobresalió, desde el comienzo, por la fuerza innovadora y la originalidad de su producción en prosa y verso. Azul... vino a ser una selección organizada de los trabajos que dio a conocer en los periódicos y, de acuerdo con sus preocupaciones del momento, fue la prosa - sobre todo en el cuento de écriture artiste- la que halló en el libro una representa-

5 Véase Raúl Silva Castro, Rubén Dario a los veinte años. Segunda edición. Santiago de Chile: Editorial Andrés Bello, 1966, capítulos 11 y 12, y nuestro artículo "Eduardo de la Barra y el primer prólogo de Azul...", Atenea [Concepción, Chile], homenaje al centenario de R. Dario, XLIV [1967], pp. 147-171. 
ción más amplia. En trance de publicarlo, la ayuda de Eduardo de la Barra resultará preciosa para Darío, en amplio sentido. $Y$ en la parte material, la colaboración directa o indirecta ${ }^{6}$ del chileno fue tan valiosa como para que éste - desmemoriado con sus favorecedores- la consignara en Historia de mis libros con las siguientes palabras:

Azul... se imprimió en r888 en Valparaíso, bajo los auspicios del poeta De la Barra y de Eduardo Poirier.?

De mayor alcance que la ayuda económica - sobre la que no tenemos precisiones-, es la aceptación de De la Barra para escribir el prólogo deseado por Darío para su obra. Prólogo que no se revela como el resultado de un compromiso cumplido al vuelo, sino como un estudio ponderado, extenso, comprensivo, provisto de filos polémicos, cuyos valores y adivinaciones aprovechará Valera en sus dos "cartas americanas" sobre $A z u l \ldots$, más tarde el prólogo "oficial" de la obra, sellando su deuda con el chileno con inexplicable silencio. Ese "prólogo invasor" -como lo llamó Manuel Ugarte, pecando de ligero- nos deja apreciar el respeto que De la Barra sentía por la obra promisoria de Darío, el alcance de su comprensión crítica y la seguridad de hallarse frente a un artista de subido valor. Los vaticinios del instante sólo los confirmaría la evolución posterior del poeta y el tiempo dio la razón a su primer exégeta de importancia. No olvidemos que el espaldarazo de Eduardo de la Barra es tanto más significativo por provenir de un hombre formado en las apetencias estéticas de otra generación -había nacido en 1839. Cuando muchos coetáneos de Darío lo negaban, surge para explicar su arte una figura magistral que penetra con inusitada lucidez en su obra. Por tales razones no es justo el olvido que rodea al estudio, ni aceptable seguir viendo en él lo que en sus días creyeron encontrar ciertos pareceres hipercríticos, para los que De la Barra era un roedor de la gloria dariana: torcidas intenciones del prologuista o reticencias disimuladas entre dudosas alabanzas. ${ }^{\mathbf{B}}$

6 Según Julio Saavedra Molina, de la Barra habría obtenido colaboración económica de Federico Varela paral la publicación de Azul... Ello explicaría la dedicatoria ditirámbica incluida en la primera edición, que el poeta sustituye en la segunda por otra brevísima a Francisco Lainfiesta, su amiogo y protector. Julio Saavedral Molina, Bibliografía de Rubén Darío, Santiago: Revista Chilena de Historia y Geografía, 1946, p. 29: "La edición fue costeada por don Federico Varela, gracias al empeño que puso de la Barra, cuyo prestigio tenía gran poder sobre el rico minero, entonces senadot".

7 Rubén Darío, Historia de mis libros, Obras completas, t. I, Madrid: Afrodisio Aguado, 1950, p. 197.

8 La especie empezó a circular muy temprano y se repite hasta nuestros 
Al aceptar la redacción del prólogo, De la Barra dio al poeta una muestra contundente de solidaridad literaria: Darío no había pensado en él primitivamente. Solicitó dicha presentación a don José Victorino Lastarria, pero el anciano maestro falleció en iunio de 1888 sin escribir el estudio. Por lo mismo, De la Barra contó con un breve plazo para preparar las treinta y una páginas impresas a que alcanza el proemio en la primera edición, concluida el último día de julio, según leemos en el colofón.

Tal como se encuentra en la edición de $x 888$, el prólogo escrito por De la Barra ocupa las páginas III a XXXIV y se distribuye en once capítulos de varia extensión. Siguiendo una modalidad muy suya -el desarrollo dialoguístico que empleaba en sus prosas satíricas-, el autor conversa con unas imaginarias "señoritas" a las que "explica" forma y contenido de la obra con "pluma charladora", de dinámica andadura externa. Aquí y allá el gusto actual choca con afirmaciones que hoy parecen pueriles o con párrafos amenazados por "lo cursi". Lo que acaso no distinguía el lector de fines de siglo, puede ser hoy un rasgo resaltante. Mas es preciso recordar cuánto nos separa del ámbito cultural en que se gestaron dichas páginas.

Empieza De la Barra por establecer que Dario es un artífice tanto del verso como de la prosa: es "un poeta verdadero, siempre artista, sea que suelte al aire las alas azules de sus rimas, sea que talle en rubíes y diamantes las facetas de su prosa" (p. III). El prologuista se muestra confiado en que "Darío llegará a ser una gloria americana" (p. V) si tiene posibilidades de desarrollar su arte o no cede a las naturales "fogosidades del numen".

El concepto que el autor exhibe de la poesía como instrumento meliorativo, humanitario, normativo y hasta docente, le lleva a expresar ideas muy opuestas a las del escritor nicaragüense, fundamento de las diferencias estéticas que les separarían. Según De la Barra, el poema o el cuento serán "estrella que guíe", "alas de águila que levantan" (p. V), porque "La regla sería: la ficción para hacer resaltar la verdad; el esplendor de la imaginación propia alumbrando la razón ajena y avivando

dias. Poco después de reproducirse el prólogo de Eduardo de la Barra en el diario La Tribuna, de Santiago, Manuel Rodríguez Mendoza, en el primero de dos artículos que llevan el título "Rubén Dario" y que aparecieron en esa misma publicaciớn (agosto 31 y septiembre $1^{\circ}, 1888$ ), escribía que el prólogo del autor chileno muestra un "terreno [...] ingrato y árido, y en él hay plantas que las. timan y hieren con sus espinas", entte otras cosas. Hemos publicado los dos artículos citados y las tres altivas respuestas de De lai Barra, con el título de "Una polémica sobre $A z u l$..., precedidos de una introducción, en el Boletín del Ins. tituto de Literatura Chilena, VI [1967], núms. 13-14, pp 37-51. 
la conciencia, la imagen para esculpir el pensamiento que inclina a la virtud y eleva la inteligencia" (Ibid). Sin duda, De la Barra tributa a los manes de su formación, tan distinta de la que exhibe Darío. Y en la entonces debatida cuestión del arte por el arte el crítico chileno está más cerca de postulados huguescos - lo útil, en vez de limitar lo sublime, lo engrandece- que de aquellos sustentados por Gautier y que ya entusiasmaban a Darío - lo bello, en cuanto se hace útil, deja de serlo.

Esta inclinación de la exégesis escrita por De la Barra no puede haber sido grata a quien creía - en la línea de su admitación por Gautier y los parnasianos - en un arte desinteresado y ajeno a todo utilitarismo cívico o ético. "La obra — anota De la Barra - que, deleitando, consiga dar luz a la mente y palpitaciones al corazón helado, si aviva la conciencia, si mueve a las acciones nobles y generosas, si enciende el entusiasmo por lo bueno, lo bello y lo verdadero, si se indigna contra las deformidades del vicio y las injusticias sociales y hace que nos interesemos por todos los que sufren, decid que es obra elocuente y eminentemente poética" (Pp. VI-VII). El fragmento parece una afirmación zolesca arrancada de Le Roman Expérimental; las formas de literatura que propiciaba Darío iban por muy otro camino. Si él protesta, al menos en esta época, es por las injusticias cometidas contra el artista y el talento creador, por la incomprensión que ante el arte revela el "burgués ignaro".

De la Barra considera que el autor de $A z u l . .$. "es de la escuela de Víctor Hugo" (p. VIII), y lo ve como un resonador de muchas otras y disímiles voces: Paul de St. Victor, d'Amicis, Alphonse Daudet, B. de Saint Pierre, Jorge Isaacs... Mas, a pesar de su variada, múltiple inspiración y de la suntuosa ars combinatoria de estilos diversos que practica, la dicción del poeta resulta nueva y original. Las adivinaciones de De la Barra frente al arte dariano son concretas e irredargüibles; se trata de la primera cala incisiva en una característica del poeta, la de crear sobre la base de entretejidas experiencias de cultura, en la línea de preferencias de los "decadentes" franceses:

Son en verdad estilos y temperamentos muy diversos, mas nuestro autor de todos ellos tiene rasgos y no es ninguno de ellos. Ahí precisamente está su originalidad. Aquellos ingenios diversos, aquellos estilos, todos aquellos colores y armonías, se aúnan y funden en la paleta del escritor centroamericano, y producen una nota nueva, una tinta suya, un rayo genial y distintivo que es el sello del poeta. De aquellos diferentes metales que hierven juntos en la 
hornalla de su cerebro, y en que él ha arrojado su propio corazón, al fin se ha formado el bronce de sus azules.

Su originalidad incontestable está en que todo lo amalgama, lo funde y lo armoniza en un estilo suyo, nervioso, delicado, pintoresco, lleno de resplandores súbitos y de graciosas sorpresas, de giros inesperados, de imágenes seductoras, de metáforas atrevidas, de epítetos relevantes y oportunísimos y de palabras bizarras, exóticas aún, mas siempre bien sonantes (p. VIII).

Dario, pues, es él - "él es él", p. XVIII-, a pesar del coro de voces que, aquí y allá, suenan y resuenan: el eco de Valera repetirá "Usted es usted", en su crítica consagratoria.

Al preguntarse De la Barra por los rasgos "decadentes" de Darío, sostiene que de ellos le acompaña la "fiebre de originalidad", pero no "las extravagancias características..., por más que tenga las inclinaciones" ( $p . X V)$. Muestra los riesgos de "los incautos que pretendan seguirlo" (Ib.), es decir, se anticipa al coro de rubendariístas, y establece el linaje poético del autor con el Traité du verbe, de René Ghil, que halla claramente expresado en el artículo de 1888 "Catulo Mendès. Parnasianos y decadentes", "donde él mismo se pinta de cuerpo entero y descubre los procedimientos que emplea" (Ib.). Así, tal artículo es la poética pertinente al libro que le sigue. Darío no hará sino poner en ejercicio lo que admira en Mendès:

Escribe en prosa y casi rima; admirable fraseador que esmalta y enflora sus cuentos y que para distinguirse tiene el sello de su estilo, de su manera de escribir como burilando en oro, como en seda, como en luz ( $\mathrm{p}$. XVI).

Otro acierto de Eduardo de la Barra es el de precisar la función del galicismo estilístico en la lengua poética dariana, como recurso de originalidad. En la obra del escritor que prologa aparecen "algunos graciosos galicismos $[\ldots] \mathrm{y}$, si anda a caza de novedades, jamás olvida el buen sentido, ni pierde el instinto de la rica lengua de Castilla al amoldar las palabras a la orquestación poética" (p. XVII). Novedades y rarezas podrían ser absueltas "hasta [por] los más empecinados hablistas" (Ib.). De la Barra da en lo justo: el galicismo lingüístico dariano realza su expresión poética y el crítico lo aprueba al distinguir en la prosa del nicaragüense "el corte francés, moderno, brusco, breve, ner- 
vioso", por sobre el tradicional "desarrollo grave, amplio, majestuoso de la frase castellana" (Ib.).

Pero el prólogo también contiene censuras. En ellas seguirá insistiendo De la Barra durante varios años, como se aprecia en El endecasílabo dactílico, de 1895 , ardorosa defensa de Darío ante los ataques de "Clarín". "Acaso se apega demasiado a la forma", escribe en la página VIII del prólogo. Además objeta lo que considera exceso ornamental: "esmalta y enflota demasiado" (P. IX) y ello puede constituir una manera imitable, un breve camino para llegar a convertirse en moda, en escuela de apego externo, en ese rubendarí́smo -antimodernismo- que el propio Darío censurará más tarde con energía.

De la Barra, que había leído y meditado el manifiesto dariano de I888 - "Catulo Mendès. Parnasianos y decadentes"-, verdadera "arte poética" para explicar el próximo $A z u l \ldots$, alude a una de las adoraciones del nicaragüense con estas palabras: "la secta moderna de simbolistas y decadentes, esos idólatras del espejeo de la frase, de la palabra relumbrosa y de las alteraciones bizantinas" (p. XI), y concluye el fragmento con la oposición del "colorete" - los lujosos préstamos ajenos, el ornato, para él excesivo- y "las rosas de la juventud", más el consejo de sanidad literaria que rechaza el capricho y los maquillajes de la retórica a la moda: “¡Fuera el oropel! ¡Fuera lo artificioso, oh jóvenes, y soplará un aire sano sobre las letras como sobre las flores del campo!" (Ibid).

De la Barra, como muchos escritores de su tiempo - herederos de la lección de Lastarria-, propende a un definido americanismo o nacionalismo literario. Aunque las conocía bien, y hasta mejor que algunos epígonos de Darío, es natural que se muestre enemigo de literaturas de importación que pueden sepultar o por lo menos ahogar la búsqueda de la apetecida originalidad: la que se funda en la meditada exploración de un mundo propio.

El prólogo escrito por el chileno nunca satisfizo del todo - desde el punto de vista estético- al autor de Azul... Son dos conceptos del arte, entre sí irreconciliables, los que pugnan en su texto y en las páginas que lo presentan. La veloz evolución del poeta explica que después de la segunda edición del libro (I890) lo destierre por completo; y si a esto sumamos las diferencias personales entre ambos escritores en su nuevo encuentro en Argentina, comprenderemos el abandono de las primeras observaciones críticas de categoría sobre $A z u l \ldots$.

9 Véase, para más detalle, nuestro artículo citado en la nota 5. 
De La Biblioteca, publicación sustentada por Paul Groussac en Buenos Aires entre 1896 y I898, pudo decir Darío: ". . La revista más seria y aristocrática que hoy tenga la lengua castellana $[\ldots]$, nuestra Revue des Deux Mondes'. El poeta fue uno de los colaboradores más asiduos de la fugaz revista y en ella Groussac, a veces a regañadientes, dio amplio ingreso a la literatura del modernismo, como creemos haber demostrado en otras páginas. ${ }^{10}$ El maestro galo-argentino dio a conocer en La Biblioteca, cuando recién se publicaban, dos valiosos artículos críticos sobre Los raros y prosas profanas, que merecen un lugar destacado si se considera a los primeros críticos de la poética dariana. ${ }^{11}$

Los dos artículos de Groussac volvieron a publicarse en $E l$ Cojo Ilustrado,12 reaparecieron en el homenaje de Nosotros a Darioli3 $\mathrm{y}$, más recientemente, los reprodujo Antonio Pagés Larraya en el Anuario de Letras de Ia Universidad Nacional Autónoma de México. ${ }^{14}$

En el primer artículo, sobre Los raros, el autor de Fruto vedado ejerce una crítica severa sobre las idolatrías artísticas de Darío, si bien nos dice:

Ante todo, le alabaré porque vive de poesía, despreocupado de cuanto no sea el arte sagrado y su culto ideal. Como el ave y el lirio del Evangelio, él no hila ni siembra, pero es la verdad que "Salomón en su gloria" no es más esplendoroso que su ilusión. $\mathrm{Ha}$ elegido la mejor parte. Después de soñar, lo mejor de la vida es recordar su sueño; ya es menos sabio acosar al misterio, dirigiendo a la eterna Isis velada preguntas indiscretas que no contestará. ${ }^{15}$

El artículo sobre Los raros concluye con una admonición situada en el tono de las inquietudes americanistas del siglo $\mathrm{XIX}$, puntos en los que Groussac expone juicios enérgicos en torno al mimetismo literario del poeta:

10: "Rubén Darío y el modernismo en La Biblioteca". La Torre, Puerto Rico, núms. 55-56, homenaje a R. Darío. Véase, asimismo, el capítulo "Darío y Groussac", en el libro de Emilio Carilla, Una etapa decisiva de Dario. (Rubén Dario en la Argentina). Madrid; Editorial Gredos, 1967, pp. 77-86.

11 "Los raros, por Rubén Dario", La Biblioteca, t. I [1896], t. II, pp. 474. 480; "Prosas profanas, por Rubén Darío", t. II [1897], t. III, pp. 156-160.

12 El Cojo Ilustrado, Caracas, VIII, pp. 158, 160-162.

13 Nosotros, Buenos Aires, febrero de 1916.

14 Anuario de Letras, II [1962] pp. 236-244. Los precede una breve introducción que ocupa las pp. 233-235. Las citas que haremos siguen esta republicación.

15 Ibid., p. 236. 
...faltaría después averiguar si la imitación del neobizantinismo europeo puede entrañar promesa alguna para el arte nuevo americano, cuya poesía tiene que ser, como la de Whitman, la expresión viva y potente de un mundo virgen, y arrancar de las entrañas populares, para no tornarse la remedada cavatina de un histrión. El arte americano será original o no será. ¿Piensa el señor Darío que su literatura alcanzará dicha virtud con ser el eco servil de rapsodias parisienses, y tomar por divisa la pregunta ingenua de un personaje de Coppée:

\section{Qui pourrais-je imiter pour être original ${ }^{16}$}

En su aproximación a Prosas profanas, Groussac se muestra más benévolo - - menos severo- que con Los raros. En cualquier caso, es ostensible que - desde la atalaya de mayor experiencia y formación más decantada- desea orientar al joven poeta. La misma pluma que había estampado el ser o no ser del arte americano a través de su búsqueda de originalidad, asegura ahora que "es necesario partir del postulado que, así en el norte como en el sud, durante un periodo todavía indefinido, cuanto se intente en Hispanoamérica en el dominio del arte es y será imitación". ${ }^{17}$

Siendo, pues, un hecho de evidencia que la América colonizada no debe pretender por ahora a la originalidad intelectual, se comete un abuso de doctrina al formular en absoluto el reproche de imitación europea, contra cualquier escritor o artista nacido en este continente. En principio, la tentativa del señor Darío - puesto que de él se trata ahora - no difiere esencialmente, no digamos de la de Echeverría o Gutiérrez, románticos de segunda o tercer mano, sino de la de todos los yankees, desde Cooper, reflejo de Walter Scott, hasta Emerson, luna de Carlyle. Pero, en la especie, dicha tentativa es provisionalmente estéril, como lo tengo dicho y no necesito repetirlo, porque es del todo exótica y no allega al intelecto americano elementos asimilables y útiles para su desarrollo ulterior. ${ }^{18}$ 
Pero Groussac reconoce en Prosas profanas por lo menos tres aportes principales y nada desdeñables:

a) el aligeramiento de los ritmos poéticos con respecto de la tradición establecida;

b) la renovación de la lengua poética, la contribución de una sensibilidad verbal que puede reputarse como nueva, $y$

c) la condición acaso transitoria del preciosismo formal que el libro representa, como un jalón necesario en las búsquedas del autor. Este, cuando se libere de amarras que entraban el vuelo propio, llegará a asuntros trascendentes y eternos.

Seguro vaticinio. Tras el tejido suntuoso de las Prosas... esconde su perfil el autor de los venideros Cantos de vida y esperanza.

En la fina labor de esas Prosas, profanas o místicas, se cumple un esfuerzo que no será de pura pérdida, como no lo es el de los decadentes franceses; me refiero al assouplissement de los ritmos y al enriquecimiento evidente de la lengua poética. El señor Dario es muy joven; sobrevivirá sin duda al movimiento perecedero y fugaz a que se ha adherido, por desdén explicable de la actual indigencia española. Tengo para mí que, a pesar de las apariencias contrarias, su talento real se escapará en breve de su falsa teoría, como un pájaro de la jaula; y entonces cantará libremente la verdad y la vida, con una eficacia y maestría de que dan bella muestra algunas piezas de su presente colección. ${ }^{19}$

Groussac precisa el rango de la mímesis poética de Darío: en ella hay una manera y ésta "es en el fondo la de los clásicos, y él imita a los franceses como imitaron a los griegos Catulo y Chénier".20 Señalado tal deslinde entre el imitador ramplón, carente de voz propia y el delicado orfebre que es Darío, Groussac analiza el poema inicial de Prosas profanas, "Era un aire suave", para establecer lo sutil del procedimiento creador que en él subyace:

Es muy difícil y aventurado mostrarse afirmativo y preciso, tratándose de un escritor tan complejo y lector tan esparcido como el señor Darío. Son muy numerosas las resonancias que convergen a su inspiración: pasa tanta gente por su camino que las huellas

19 Ibid, ibia.

20 Ibid, p. 243. 
se confunden $y$, como decimos los arrieros: "El rastro está borrado".21

El estudio del poema es la primera crítica de categoría sobre unos versos que -al decir de Pedro Salinas- trajeron a la poética castellana una sensibilidad antes desconocida:

La página es encantadora, de una gracia exquisita en su elegancia, complicada de renacimiento y pompadour. Por otra parte, más que imitación directa encuentro en ella vagas y múltiples reminiscencias de Verlaine (Fêtes galantes), Moréas - sobre todo, para mí, de la divina Fête chez Thérèse de ese Hugo colosal que hizo vibrar soberanamente las siete cuerdas de la lira, hasta la de gracia ligera, que comúnmente se le niega. ${ }^{22}$

Groussac presenta en seguida la síntesis crítica más acabada de esa etapa dariana, que sólo superará, poco más tarde, en I899, la exégesis de Rodó:

Para ser completo y justo, hay que saborear la pieza misma con sus mil detalles del estilo: la cincelada orfebrería de las palabras, nombres, verbos y adjetivos de elección, que se engastan en la trama del verso como gemas en filigrana; el perpetuo hallazgo - itan nuevo en castellano! - de las imágenes y ritmos evocadores de la sensación, en que se funden ciertamente elementos extraños, pero con armonía tan sabia y feliz que constituye al cabo una inspiración. $Y$, sin duda alguna, ello es arte de más conciencia que emoción, como el mosaico: pero, como éste, lo es también de gusto y concepto: hubo maestros mosaístas, y aun los de Bizancio dejaron obras dignas de eterna admiración. 23

El fragmento con que concluye Groussac su estudio de Prosas profanas es suficiente para mostrar que se equivocan quienes sostienen que el autor francoargentino era un enemigo disfrazado del modernismo, cuya actitud era admitirlo en las páginas de La Biblioleca para luego demolerlo a sabor:

21 Ibid., ibid. Subrayamos esparcido ['dilatado'], que no sugiere tono restrictivo sino alabanza por parte de Groussac.

22 Ibid., ibid.

23 Ibid., ibid. 
El señor Darío, pues, tiene personalmente razón contra sus detractores faltos de iniciación, o de buena fe; pero sus críticos imparciales tienen razón contra su teoría -aunque la expresase mejor que en las Palabras liminares-y él mismo les suministra argumentos de buena ley, pues la mayor y mejor parte de sus Prosas profanas no difieren exteriormente de las formas ya conocidas en castellano - sino por lo acabado de la cinceladura y, sobre todo, por el licor exótico e inquietante que en ellas nos sirve. Por mi parte, y en dosis prudente la bebida no me perturba ni disgusta; pero comprendo que otros estómagos no la soporten: esta doble forma de la tolerancia es un privilegio del espíritu crítico. Por lo demás, yo soy un griego de Focea, amante de la luz y bebedor de vino; de ningún modo un fumador de opio "poderoso y sutil": pero mi cabaña tiene galería abierta hacia los cuatro vientos y está construida ante un vasto horizonte, sobre un promontorio que domina el mar. ${ }^{24}$

¿Cómo reaccionó Darío ante las observaciones de Groussac? No lo sabemos en planos de intimidad o de epistolario. Hay, sí, un importante artículo del poeta, en que responde a la crítica sobre Los raros. Trátase de "Los colores del estandarte", que vio la luz en La Nación, el 27 de noviembre, 1896 , artículo de sobra conocido por Groussac cuando enjuició el libro siguiente de Darío. ${ }^{25}$

Sea lo que fuere, por el respeto que a Darío le merecía la obra creadora y crítica de Groussac - uno de sus maestros en la nueva prosa, como el propio poeta declaró-, no dejarían de inclinarlo a meditación tales ideas ni carecerían de influjo en las venideras direcciones de su arte.

En su esfuerzo por tasar con justicia los valores de Prosas profanas hizo Groussac evidente que no siempre derivaba a merced del "placer desinteresado en el desdén", como afirma un argentino ilustre.

III

El escritor y político paraguayo Manuel Gondra es el autor de una de las censuras más orgániças y minuciosas a las ideas estéticas que, en

24. Ibid., p. 244 .

25 "Los colores del estandarte" apareció en La Nación de Buenos Aires, noviembre 27 de 1896. Reproducido en Escritos inéditos de Rubén Dario, editados por Erwin K. Mapes, New York: Instituto de las Españas en los Estados Unidos, 1938, pp. 120-123. 
los tiempos de Prosas profanas, difundía Rubén Darío en Buenos Aires. El ensayo de Gondra, poco conocido fuera de Paraguay hasta que lo publicó José Natalicio González en $1942,{ }^{26}$ mereció hace pocos años un amplio estudio revalorador de Mariano Morínigo. ${ }^{27}$ Fue concebido como una extensa carta crítica que Gondra dirigió a Francisco L. Bareiro, joven paraguayo entonces residente en Valparaíso, y vio la luz en La Democracia, periódico asunceño, con el título de "En torno a Rubén Dario".

La crítica de Gondra, fechada el 25 de enero de I898, constituye, en medio del vocerío de ataques y alabanzas que cercaban al autor de Los raros, una de las pocas opiniones dignas de audiencia y atención. Quien la firma no es un crítico desestimable, aun cuando llega a desenfocar su apreciación de Dario en la etapa de evolución representada por Prosas profanas. Por algo éste le llamará más tarde "el noble y culto Gondra".28 Hay que teconocer en Gondra, por otra parte, una altura de propósitos que no alcanza, por ejemplo, el ceñudo "palique" de Clarin -el novelista admirable de La Regenta-que declaró a Darío sólo "medio poeta", ataque al que el poeta supo, sin duda, bien responder en "Pro domo mea". ${ }^{29}$

Gondra inicia sus apreciaciones historiando su propia desilusión de lector del poeta: de la hipérbole admirativa — dice - ha pasado a una posición escéptica que le conduce a negarlo - y a los modernistas en su conjunto- por no haber aportado novedad alguna a la literatura en español. (Lo que, con la perspectiva de fines de siglo solamente, no se podía aún decretar). Razón concreta del desencanto: las "Palabras liminares" de Prosas profanas, ya que sólo a ellas y no al conjunto a que sirven de pórtico se refiere el ensayista paraguayo:

He sido admirador de Rubén Darío y continúo siéndolo, pero mi opinión acerca de su personalidad literaria ha cambiado casi fundamentalmente. Cuando por primera vez lei sus poesías y su prosa cincelada y rica, me pareció escuchar acentos para mí nuevos de la lira americana, y sentí honda admiración por el joven y eximio artista, que por modo tan original surgía de entre la turba de endecasilabistas gemebundos y "decimeros" heroicos, que tanto

225 Manuel Gondra, Hombres y letrados de América. Prólogo de J. Natalicio González. Asunción: Editorial Guarania, 1942, pp. 201-240.

27 Mariano Morínigo, "Capítulo antimodernista en la literatura paraguaya". Revista Nacional de Cultura, Caracas, t. XXVI [1964], núm. 163, pp. 31-66.

28 En el artículo " $\mathrm{El}$ " Brasil intelectual", refiriéndose a destacadas figuras de las letras hispanoamericanas. Obras completas, t. I, edición citada, p. 499.

29 La Nación, Buenos Aires, enero 30 de 1894. Reproducido en las pp. 50-51 de Escritos inéditos..., edición citada. 
en la madre patria como en nuestra América se han desatado en bárbaro aluvión de mediocridad. 30

La caída de Darío desde el pedestal de su estimación antes entusiasta ("los elogios que de él leía me parecían injuriosos por lo mezquinos, como hermosamente dijo Cánovas de los que a Cervantes dirigiera Lope de Vega") se debió en Gondra a lo manifestado en la presentación teórica de las Proscss. A nadie pasará inadvertido el orgullo artístico de Darío en el altivo proemio, que contiene una censura aguda a lo que inquietaba al poeta por entonces: la carencia de oficio en artistas más adivinadores que conscientes; la falta de elevación mental; el desconocimiento del propio arte en los creadores no modernistas; la proclividad improvisadora, hija deforme de facundias expresivas y del culto a la inspiración arrebatada de los románticos.

Lo que más ha contribuido a rebajarle del alto pedestal que mi entusiasmo le levantara han sido las Palabras liminares de sus Prosas profanas. Insinuándose en ellas como depositario de una doctrina artística, cuya revelación hará el día en que la intelectualidad americana haya subido de nivel, Darío ha venido a colocarse en una posición bien difícil, porque, y esto es lo que hoy pienso, los modernistas de América, él inclusive, no han aportado nada, absolutamente nada nuevo, ni al acervo de la estética universal, ni al de la técnica literaria castellana.31

En opinión de Gondra, Darío no puede presentarse, a través del evangelio estético de las "Palabras liminares", como "Mesías de un arte nuevo", justamente porque es el suyo un arte que deja ver su filiación femenina, mimética: ha necesitado de la fecundación que el contacto con otras literaturas le aporta. Nada original puede postular - parece razonar el crítico- quien no lleva en sí mismo una invariable voluntad de ser original, quien no corta de un solo tajo influencias, lecturas, tradición cercana o remota.

Admirabilísimo artífice de versos él, no hallo en toda su obra lo que pueda autorizarle a presentarse como tal Mesías de un arte nuevo, siendo sí y esto no se podrá negar, un prodigioso talento de imitación el suyo, talento que necesita dar una nota personal, propia,

30 Hambres y letrados..., p. 204.

31 Ibid., pp. 204-205. 
para que se le distinga de los diversos grupos poéticos en que fragmentariamente puede ser colocado. 32

De su examen de puntos fundamentales de las "Palabras liminares", extrae Gondra consecuencias negativas que muestran -a su juicio- lo insostenible de dichos principios estéticos: a) si hay "falta de elevación mental de la mayoría pensante" continental, Darío no es justo con ella, pues ésta "reconoció y aplaudió su talento desde que dio sus primeros frutos, y hasta hoy le aplaude, como es cierto y como es justo, ¿por qué no habría de comprender la doctrina que informa aquellas mismas obras?".33 b) "Si los mejores talentos de entre los nuevos de América ignoran por completo el arte que cultivan, ¿por qué esa obstinación en mantenerlos todavía a oscuras, en ocultarles la palabra mágica que ha de abrirles el sésamo misterioso de la nueva doctrina?".34 c) La proclamación de "una estética acrática" es para el crítico "una adorable petulancia del poeta, petulancia que no irrita porque es ingenua, pero que hace sanreír ante los briosos alardes del reformador". ${ }^{35}$

Tras la glosa de otros aspectos de las "Palabras liminares", Gondra se enfrenta con aquello que "podría juzgarse como lo único nuevo que se halla" en tal introducción teórica, "y eso por la forma dogmática en que se expresa":

Si hay poesía en nuestra América, ella está en las cosas viejas, en Palenque y Utatlán...

Considera Gondra que tal afirmación niega al poeta el acceso a la generosa cantera decimonónica de la naturaleza y los asuntos históricos americanos. El ancestro de dicha opinión es fácilmente discernible: se remonta al americanismo poético tal como lo entendió, al comenzar el siglo $\mathrm{xIX}$, don Andrés Bello en el programa de las Silvas americanas. Pero es evidente que a Darío no interesaba la prolongación del canto a la naturaleza, estremecedor lugar común de un siglo de poesía, ni deseaba aproximarse apostróficamente a la historia -y de ésta a las grandes batallas, o los grandes estrategos, a la manera de un Olmedo- porque su postura estética le exige más un enfrentarse ensimismado que un remedo objetivo. Él diría más tarde, en su recuento de la situación poética del

\footnotetext{
32 Ibid., p. 205. El subrayado es nuestro.

33 Ibid., p. 209.

34 Ibid., ibid.

35 Ibid., ibid.
} 
siglo $\mathrm{XIX}$, cuáles eran los asuntos necesariamente evitables de una lírica empedernida en el clisé: "Pues no se tenía en toda la América española como fin y objeto poéticos más que la celebración de las glorias criollas, los hechos de la Independencia y la naturaleza americana: un eterno canto a Junín, una inacabable oda a la agricultura de la zona tótrida, y décimas patrióticas". 36

Gondra le pide, pues, que regrese a los asuntos que Darío poéticamente abomina. En sendero de mejor razón le hallamos cuando objeta el "silencio de Darío sobre los estados afectivos del alma americana, como materia de producción artística". ${ }^{37}$

La indiferencia dariana ante ciertos aspectos de una poética americanista es explicada por Gondra a la luz de las características de su imaginación creadora, de naturaleza "retroactiva", necesitada siempre de volver al pasado, pues no recoge los indicios de lo actual y sólo germina en contacto con el pretérito ya elaborado. Con lo cual Gondra señala en Darío un modo creador que produce en relación con las experiencias ya prestigiadas por las artes, esas experiencias de cultura de que Gundolf habla en el prólogo de Goethe, y que la decadencia francesa utilizó como rica cantera de creación.

La imaginación de Rubén Darío es, diré así, retroactiva. No busca los materiales de sus concepciones en la vida presente, porque hasta su sensibilidad dijérase que se niega a recibir impresiones de lo actual y circunferente y carece del sentimiento épico de la naturaleza viva y sólo se fecunda y crea cuando se pone en contacto con el pasado, ya clásico o medieval. Pero, como esta comunicación del alma del poeta con las edades que fueron, no es, como no puede serlo, obra de maravillosa intuición, sino que se lleva a cabo por la tercería de las literaturas antiguas, de aquí que su poesía no pueda menos de ser erudita y casi diría de gabinete y carezca también de ese calor de vida cuya falta tanto se nota en sus versos. ${ }^{38}$

Así, Gondra es de los primeros - ya se oirá la voz de Rodó- en afirmar que Dario no es el poeta de América, sino el creador que pide auxilio a lo europeo - sobre todo a lo francés, y a lo francés dieciochesco- para fecundar su obra:

\footnotetext{
${ }^{36}$ R. Dario, Historia de mis libros. Obras completas, t. I, edición citada, p. 206.

37 Hombres y letrados..., p. 213.

38 Ibid., p. 212.
} 
Rubén Darío, que se ha revelado poseedor de esa facultad que Menéndez y Pelayo llama "segunda vista arqueológica", tan necesaria a los que quieran labrar mármoles arrancados en las canteras de la historia, no ha demostrado, sin embargo, tener el sentimiento de América. Y creo que se entenderá bien esta expresión. Sus versos pueden leerse en toda su extensión, sin que se diga una sola vez: esas son las montañas, esas las selvas, esas las llanuras, ese es el cielo, esas las hembras o esos los varones de América. Si por casualidad se tropieza con rasgo de americanismo en sus poesías, es americanismo de pacotilla europea.

Admitiendo, pues, que esa fuente de inspiración que indica pueda ser fecunda, como será original, creo que no es su musa, muy acostumbrada ya a las cumbres griegas y a las orillas de los mares jónicos, la que podrá ofrecer en la copa cincelada del arte el agua virgen, cristalina, de caudal autóctono, a los labios americanos resecos por el prosaísmo de nuestra época.

Aunque quizá el talento artístico de Darío tenga una admirable adaptabilidad de que no ha dado aún pruebas. ${ }^{39}$

Gondra se extiende después en consideraciones métricas y rítmicas destinadas a aportar más juicios negativos sobre las novedades de Darío. Itrsistirá en que nada nuevo nos ha traído - hasta esa hora- el arte que tan severamente considera.

¿Cómo reaccionó Darío frente a tales impugnaciones? No lo sabemos con precisión. Tal vez la publicación de la correspondencia que dirigió a Gondra nos aportara alguna luz; no conocidas aún tales cartas, permanecemos en el terreno de lo conjetural.

\section{IV}

"La vida nueva será una colección de opúsculos literatios en los que me propongo reunir todas aquellas páginas mías que expresen, ya una impresión de mi conciencia de espectador en el gran drama de la inquietud contemporánea, ya una modificación de mi pensamiento propio que obedezca al actual impulso renovador de las ideas y de los espíritus". ${ }^{40}$ Con estas palabras introdujo José Enrique Rodó el primer opúsculo de

39 Ibid., p. 213.

40 José E. Rodó, Obras completas, edición de E. Rodríguéz Monegal, Madrid: Aguilar, 1957, p. 145. 
la serie La vida nueva: El que vendrá. La novela nueva, en 1897 . A éste seguirán Rubén Dario. Su personalidad literaria, su última obra, en I899; y un año más tarde, en la misma serie, Ariel. Las tres obras, impresas en Montevideo por Dornaleche y Reyes. Como puede apreciarse, la triada de ensayos rodonianos reúne su obra crítica o estimativa - la aproximación cuidadosa al quehacer de los demás- y la de expresión ideológica o ensayística original, en las páginas del libro que, publicado en I900 - balcón cronológico para avizorar el porvenir de Iberoamérica- se convirtió en el devocionario mental de toda una generación, a la que marca con su signo, indeleblemente.

El ensayo sobre Prosas profanas se divulgó, más que en la primera edición montevideana, tras su aparición como prólogo a la segunda salida del libro de Darío (I9OI), si bien fue publicado frente a éste en forma anónima, lo que motivó un distanciamiento entre el poeta y su prologuista.41

Señala la obra crítica de Rodó una singular etapa de transición en la manera de enjuiciar la literatura de Hispanoamérica. Rescatemos para ella la perspectiva finisecular y el cotejo con lo que entonces escribía en tal orden -en la Península y en Iberoamérica - exhibirá la cuantiosa diferencia que existe entre la exégesis del pensador uruguayo y sus contemporáneos. Prevalecía entre éstos, y sobre todo entre los escritores españoles - se salva algún nombre como el de Valera; Menéndez y Pelayo no solía ocuparse de autores de sus días- una visión por lo común derogativa, protectora, de las letras del Nuevo Mundo. Ejercida tal crítica, las más de las veces, con el cuentagotas gramatical, casi todo en ella se reducía no tanto a valorar con ponderación creaciones poéticas o narrativas, cuanto a una infatigable y fatigosa pesquisa de "ripios ultramarinos" -para invocar los manes de Valbuena. La cuota que Rodó agrega es doble. Por una parte, la constante creación estética que contiene su manera, que es la glosa o amplificación, el procedimiento "resonador", la paráfrasis, alzados a su mejor representación en el estudio sobre Prosas profanas ${ }^{42} \mathrm{La}$ crítica, así, se concibe como otro acto creador que prolon-

41 Véase la nota 4. Mario Benedetti escribe: "Lo que Rodó hizo, acaso inconscientemente, fue salvaguardar su conciencia de crítico, dejar sentada en el fondo su profunda convicción de que el escritor de estas tierras debía incorporarse a la miticia hispanoamericana. Claro que Dario no debe haberle perdonado semejantes sutilezas. Ya por entonces su nombre estaba en la cúspide de la poesía hispanoameticana, y no resulta arriesgado conjeturar que debe haberse sentido olímpicamente molesto. Sólo esa molestia puede explicar ciertos menosprecios (si se quiere, marginales, y siempre atribuibles a la distracción o a la negligencia de los grandes hombres) que en adelante habria de tener hacia el crítico urugulayo". Genio y figura de José Enrique Rodó, obra citada, p. 43.

42 Sobre Rodó como crítico es útil la consulta de las páginas de Emir Ro- 
gará, con beneficio para el lector, el texto comentado.* Por otra parte, "el homenaje de la equidad", la alianza del juicio sereno, ponderado - planeaba Rodó una obra que iba a llamar De la tolerancia en la crítica, nunca escrita-, con una iluminación ideológica amplia, en que se combinan variados órdenes del saber. Muy atrás quedaba, pues, cietta crítica consuetudinaria: la que resultaba de un capricho, o aquélla prohijada por la actividad periodística, con su signo distintivo, la urgencia del diarismo.

No nos sorprende así que el primer problema planteado por Rodó en su meditación de Prosas profanas sea un núcleo de apertura cuyo centro está en las indagaciones del arte "americano", sus alcances en los años finales del siglo y su encrucijada con el venidero.

"Indudablemente, Rubén Darío no es el poeta de América" -leemos en el primer párrafo, en una especie de eco razonado- de lo que sostuviera Gondra un año antes. Pero el crítico en seguida apunta que hace suyas esas palabras, no "para señalar en ello una condición de inferioridad literaria":43 circunstancias hay en el Continente que parecen dilatar "indefinidamente [...] la posibilidad de un arte en verdad libre $y$ autónomo". 4 Hemos de vivir, entre tanto, amparados en una forma que conservará por mucho tiempo el carácter mimético de nuestro arte, a pesar de los esfuerzos de su originalidad gastados en todo un siglo de búsquedas y tanteos. El parentesco con ideas del francés Groussac es, asimismo, claro, como es claro también que coinciden en conceptos de biologismo cultural -muy decimonónicos-: la América hispánica no ha vivido aún necesarias etapas evolutivas y por ello permanece en una infancia imitadora, en camino a su madurez final:

... creo pueril que nos abstinemos en fingir contentos de opulencia donde sólo puede vivirse intelectualmente de prestado. Confesémoslo: nuestra América actual es, para el Arte, un suelo bien poco generoso. Para obtener poesía de las formas, cada vez más vagas e inexpresivas de su sociabilidad, es ineficaz el reflejo; sería necesaria la refracción en un cerebro de iluminado, la refracción en el cerebro de Walt Whitman. Quedan, es cierto, nuestra Naturaleza soberbia, y las originalidades que se refugian, progresivamente es-

dríguez Monegal que forman el capitulo 5, de la segunda parte de la "Intriroducción general", Obras completas ya citadas, pp. 115 y ss.

[* Cf. Mercedes Rodríguez Galán "La crítica creadora. El ensayo de Rodó sobre Rubén Darío", en Acta Salmanticensia, Salamanca, 1956, serie "Filosofía y Letras", t. X. No.' 1, pp. 369-376.]

43 Prosas profanas, edición de 1901, por la que en lo sucesivo hacemos las citas, p. 7.

44 Ibid., p. 7 . 
trechadas, en la vida de los campos. Fuera de esos dos motivos de inspiración, los poetas que quieren expresar, en forma universalmente inteligible para las almas superiores, modos de pensar y sentir enteramente cultos y bumanos, deben renunciar a un verdadero sello de americanismo original.45

El "antiamericanismo involuntario" del autor de Prosas profanas - $\mathrm{y}$ en ese libro- se puede explicar, según Rodó, no sólo por los asuntos que poetiza, por las zonas en que hurga su imaginación creadora y por una visión de la realidad que no toma en cuenta lo que ésta le pone más cerca de su contemplación: Darío inicia un arte de exquisiteces, posee el sens des nuances, antes no ejercitado en la poesía hispanoamericana:

Habíamos tenido en América poetas buenos, y poetas inspirados, y poetas vigorosos; pero no habíamos tenido en América un gran poeta exquisito. Joya es ésa de estufa; vegetación extraña y mimosa que mal podía obtenerse de la explosión vernal de savia salvaje en que ha desbordado hasta ahora la juvenil vitalidad del pensamiento americano; algunas veces encauzada en toscos y robustos troncos que durarán como las formas brutales, pero dominadoras, de nuestra naturaleza, y otras muchas veces difusa en gárrulas lianas, cuyos despojos enriquecen el suelo de tierra vegetal, útil a las florescencias del futuro.46

Darío aplasta, de tal modo, la facilidad y la improvisación román. ticas, los dictados verbosos de la inspiración y la burda visualización del delirio creador ("Dadme mi lira, dádmela..."): trae algo "que tampoco es fruto fácil de hallar, dentro de la moderna literatura española, el de la exquisitez literaria; entendiendo por tal la selección y la delicadeza que se obtienen a favor de un procedimiento refinado y consciente". ${ }^{\prime 7}$ Darío, en el parecer de Rodó, es de los primeros en aportar, frente a una literatura que surge de cierto falso sonambulismo exterior, otra que sancionara en las "Palabras liminares", al referirse al desconocimiento en muchos creadores del mismo arte al que creen contribuir.

Asimismo consigna Rodó la distancia entre el arte "desinteresado" de Darío, "la índole esencialmente refinada y erudita de la poesía de este libro", 48 y la tradición - generosa sobre todo en el romanticismo y

\footnotetext{
45 Ibid., pp. 7-8.

46 Ibid., p. 9.

47 Ibid., ibid.

to Ibid., p. 44.
} 
su secuela- de poetas que combaten con su pluma, que visten el levitón político, hacen leyes y combaten con sus estrofas al tirano, saludan al progreso o se conduelen apostróficamente de las postergaciones sociales:

...toda manifestación de poesía ha sido más o menos subyugada en América por la suprema necesidad de la proparanda y de la acción. $\mathbb{E l}$ arte no ha sido, por lo general, sino la forma más remontada de la propaganda; y poesía que lucha no puede ser poesía que cincela. Este utilitarismo batallador que, bien o mal depurado de la inevitable escoria prosaica, aparece en casi todas las páginas de nuestra Antología, basta para que resalte con un enérgico relieve de originalidad la obra, enteramente desinteresada y libre, del autot de $A z u l$... No cabe imaginar una individualidad literaria más ajena que ésta a todo sentimiento de solidaridad social y a todo interés por lo que pasa en torno suyo. ${ }^{49}$

En cuanto a las cosas de la tierra, ellas sólo ofrecen, para nuestro artista, un interés reflejo que adquieren de su paso por la Hermosura, y que se desvanece apenas han pasado. Frente a la realidad positiva, a las que el Evangelio llama disputas de los hom. bres, a todo lo oscuro y lo pesado de la agitación humana, su actitud es un estupor exotérico o un silencio desdeñoso. Nada sino el arte..$^{50}$

El crítico - aún detenido en el marco introductor de su amplio cuadro exegético - destaca, además de la "naturaleza literaria" de Darío, cierto don -o defecto- - de suma mesura, de congelación sentimental, "un parnasianismo extendido al mundo interior", 51 que asordina todo grito, toda expresión pasional: "Nunca el áspero grito de la pasión devoradora e intensa se abre paso al través de los versos de este artista poéticamente calculador, del que se diría que tiene el cerebro macerado en aromas y el corazón vestido de piel de Suecia". 52

Hay en el autor de Prosas profanas un "amaneramiento voula de selección y de mesura que le caracteriza en el sentimiento, $[y]$ le domina también en la descripción". ${ }^{3} \mathrm{El}$ mundo que el poeta ordena no responde a solicitaciones de la realidad externa: se va construyendo por combinaciones sabias de lecturas, de comercio con otras artes, para formar, así, un modo de segunda realidad que resulta de experiencias elaboradas, de

\footnotetext{
49 Ibid., p. 10.

50 Ibid., p. 11.

51 Ibid., p. 15.

52 Ibid., p. 12.

53 Ibid., pp. 12-13.
} 
combinaciones suntuosas de un sueño exquisito que no sería tal sin las incursiones librescas y las peregrinaciones culturales por patrias distantes:

Está lleno de imágenes, pero todas ellas son tomadas a un mundo donde genios celosos niegan la entrada a toda realidad que no se haya bañado en veinte aguas purificadoras. Porque Rubén Darío sería absolutamente incapaz de extraer poesía de las excursiones en que el pie felino de la musa de Baudelaire hollaba, con cierta morbosa delectación, el cieno de los barrios inmundos [...] Ve intensamente, pero no ve sino ciertos delicados aspectos del mundo material. La intensidad de su visión se reserva para las cosas hermosas. Cierra los ojos a la impresión de lo vulgar [...] Todas las formas que ha fijado en el verso revelan ese mismo culto de la plasticidad triunfal, deslumbradora, que se armoniza en él con el de la espiritualidad selecta y centelleante. El instinto del hujo - del lujo material y el del espíritu-, la adoración de la apariencia pulcra y hermosa, con cierta indolente non curanza del sentido moral. ${ }^{54}$

Lo riesgoso del arte dariano, tal como Rodó lo enjuicia a través de Prosas profanas, es que llegara a convertirse en solicitación de "escuela", dejando de ser su condición -artísticamente aceptable - un "signo de una elegida individualidad".

La visión estéticamente selectiva, el deseado enajenamiento de la preocupación social que exhibe el poeta, no harán sino limitarlo a gustos de minoría, restándole popularidad. Bien lo sabía Darío y es, por entonces, el camino que buscaba, como deja ver en las "Palabras liminares", al fundat una poética en consonancia con la modernidad: ensimismamiento, complacencia en un arte cerrado, para elegidos, satisfecho es su rareza y en la niebla simbólica que gusta de crear su "individualismo soberbio", como lo llama Rodó:

Todas las selecciones importan una limitación, un empequeñecimiento extensivo; y no hay duda de que el refinamiento de la poesía del autor de $A z u l .$. la empequeñece del punto de vista del contenido humano y de la universalidad. No será nunca un poeta popular, un poeta aclamado en medio de la vía. El lo sabe, y me figuro que no le inquieta gran cosa. Dada su manera, el papel de representante de multitudes debe repugnarle tanto como al poeta de

5. 3bid., p. 13 
las Flores del mal, que, con una disculpable petulancia, se jactaba de no ser lo suficientemente bête para merecer el sufragio de las mayorías... ${ }^{55}$

Al final de la parte introductoria se pregunta Rodó, establecido "el único quicio inconmovible" del poeta, la "absoluta pasión por lo selecto y por lo hermoso":

... oigo que me pregunta una voz interior que se anticipa a muchas voces extrañas: ¿No crees tú que tal concepción de la poesía encierra un grave peligro, un peligro mortal para esa arte divina, puesto que, a fin de hacerla enfermar de selección, le limita la luz, el aire, el juego de la tierra?56

La segunda parte del estudio de Prosas profanas - la más dilatada-, es la aproximación a los poemas más representativos del libro; ha de recordarse que el crítico sólo juzga la primera versión -considetablemente más breve-- del libro, la de 1896 , si bien al incluirse en la segunda edición sirvió como prólogo a la forma definitiva de las Prosas...

Establece Rodó sin ambages que no es éste el tipo de literatura que él mas apetece. El ámbito dieciochesco recreado con primor por Darío sólo le "agrada de una manera mediana". No podía ser de otro modo: el pensador que es, aunque declare su adscripción al modernismo ("yo soy un modernista también..."), encaja sólo lateral, parcialmente, en el arte nuevo. Su modernismo es cauteloso, marginal, sometido a la tensa rienda ideológica que le lleva muy lejos de "la obra frívola y fugaz", del "vano producir de la mayor parte de la juventud que hoy juega infantilmente en América al juego literatrio de los colores". ${ }^{57}$ Y si Rodó acepta la lengua poética de los modernistas -elegancia plástica, musicalidad verlaineana, imaginería suntuosa, selección léxica, etc.-, lo hace sirviéndose de ella como instrumento más acertado de un modo de revelación ideológica, como se aprecia en Ariel, en que claros procedimientos de filiación modernista - los cuentos epigramáticos y simbólicos, por ejemplo- resultan ancilares con respecto del sistema de ideas que se pretende revelar.

Si la adscripción estética de Rodó a lo que representan Prosas pro.

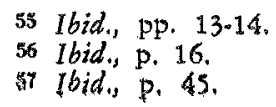


fanas es sólo mediana, como él explicita, el estudio es prueba concreta de lo que el uruguayo postulaba como virtud esencial de quien ejerce el oficio de ponderar creaciones ajenas: la amplitud simpática, "la capacidad de admirar... la gran fuerza del crítico...", s8 que él plasma en el símbolo de un infatigable Simbad de lecturas:

Presumo tener, entre las pocas excelencias de mi espíritu, la virtud, literariamente cardinal, de la amplitud. Soy un dócil secuaz para acompañar en sus peregrinaciones a los poetas, a dondequiera que nos llame la irresponsable voluntariedad de su albedrío; mi temperamento de Simbad literario es un gran curioso de sensaciones. Busco de intento toda ocasión de hacer gimnasia de flexibilidad. . . 59

Al iniciar el pormenotizado recorrido a través de numerosos poemas del libro, Rodó nos da la clave de su proceder: la sugestión poética le lleva a amplificar en la fantasía su experiencia de lector. Ello se resuclve en una paráfrasis en que el prosista compite con el poeta en la recreación del ámbito lírico, en una "confesión de impresiones". Tal método, aceptable otrora, carece hoy de validez exegética; pero situemos el estudio en su cronología y en la circunstancia de que no está dirigido a lectores especializados ni aulas de universidad: son trazos —dice Rodó- del "lápiz inquieto de mis glosas", "páginas donde he puesto en movimiento tantos modos del juicio".60 El crítico postula la licitud de tal proceder - la glosa impresionista- cuando quien lo ejerce alcanza cierta altura creadora:

¿Tocar así la obra del poeta, para describirla, como un cuadro, con arreglo a un procedimiento en que intervenga cierta actividad refleja de la imaginación, es un procedimiento legítimo de crítica? Sólo puede no serlo por la incapacidad de quien lo haga valer.61

La exégesis de los más destacados poemas del libro - de los que Rodó va extrayendo las características del arte dariano- concluye con una especie de colofón en que explaya sus relaciones con el modernismo. Nos parece que expresa claramente, a lo largo del ensayo, lo que acepta y lo que rechaza de él, contra lo que sostiene Edoardo Crema en un

\footnotetext{
s8 Ibid., p. 29.

59 Ibid., p. 17.

60 Ibid., p. 29.

1 lbid., p. 19.
} 
artículo reciente.62 Rodó llama al suyo "homenaje de mi equidad, que no es el de un discípulo, ni el de un oficioso adorador". ${ }^{63}$ Se declara él también un modernista y a ello suma el acierto de entender dicha dirección literaria como fuerza que trasciende las metas incursiones en la poesía y la prosa ya que se ordena con los caracteres de una crisis epocal. Rebasa el modernismo las lindes de la sola creación literaria, lo que es un anticipo de conceptos que treinta años más tarde maduraría el pensamiento de Federico de Onís:

No creo ser un adversario de Rubén Datío. De mis conversaciones con el poeta he obtenido la confirmación de que su pensamiento está mucho más fielmente en mí que en casi todos los que le invocan por credo a cada paso. Yo tengo la seguridad de que, ahondando un poco más bajo nuestros pensares, nos teconoceríamos buenos camaradas de ideas. Yo soy un modernista también; yo pertenezco con toda mi alma a la gran reacción que da catácter y sentido a la evolución del pensamiento en las postrimerías de este siglo; a la reacción que, partiendo del naturalismo literario y del positivismo literario, los conduce, sin desvirtuarlos en lo que tienen de fecundos, a disolverse en concepciones más altas. $Y$ no hay duda de que la obra de Rubén Darío responde, como una de tantas manifestaciones, a ese sentido superior; es en el arte una de las formas personales de nuestro anárquico idealismo contemporáneo... ${ }^{64}$

Al destacar con generosidad los méritos de Dario -a quien al mismo tiempo sanciona en lo que a su juicio va desencaminado-, Rodó le confía los tributos de una esperanza renovadora; acaso en la España de esos días logre rescatar, del silencio que sigue a la derrota, voces nuevas y se convierta en "el influjo madurador que irradia de toda fuerte empresa intelectual". El vaticinio, dicho en la hora en que Darío viaja hacia España, es el mejor homenaje de un adepto:

El poeta viaja ahora rumbo a España. Encontrará un gran silencio y un dolorido estupor, no interrumpidos ni aun por la nota de una elegía, ni aun por el rumor de las hojas sobre el surco, en la soledad donde aquella madre de vencidos caballeros sobrelleva [...] la austera sombra de su dolor inmerecido. Llegue allí el poeta llevando buenos anuncios para el florecer del espíritu en el

62 Edoardo Crema, "Rodó y Rubén Dario". Revista Nacional de Cultura, XXVIII [1966], núm. 178, p. 76: "En su ensayo sobre 'Rubén Datio', Rodó silencia en absoluto lo que él pedía al modernismo poético...".

63 Prosas profanas, p. 45 , 
habla común, que es el arca santa de la raza; destáquese en la sombra la vencedora figura del Arquero; hable a la juventud, a aquella juventud incierta y aterida, cuya primavera no da flotes tras el invierno de los maestros que se van, y enciéndala en nuevos amores y nuevos entusiasmos. Acaso, en el seno de esa juventud que duerme, su llamado pueda ser el signo de una renovación; acaso pueda ser saludada, como la de los príncipes que, en el cuento oriental, traen de remotos países la fuente que da oro, el pájaro que habla y el árbol que canta...65

Darío no tuvo en vida crítico que pueda parangonarse con Rodó - ni Valera ni el joven Henríquez Ureña de Ensayos críticos. Por lo mismo, resulta inexplicable su reacción frente al tributo crítico de Rodó. Para agradecerlo se remontó a alturas de Olimpo, el 3 I de marzo de I899: "Caro amigo: Gracias mil. Su generoso y firme talento me ha hecho el mejor servicio. Usted no es sospechoso de camatadería cenacular. Pronto le escribiré largamente. Gracias". ${ }^{66}$ Carta, la prometida, que nunca recibió el escritor uruguayo. El poeta, que a veces pagaba son "cabezas" a escritores segundones que lo adulaban o le prestaban servicios prácticos en oscuras gacetillas, no tuvo empacho en herir a Rodó con su altanero laconismo.* A ello se sumaría, en I $90 \mathrm{r}$, su sospechoso descuido al omitir la firma del autor de Arìel en la reproducción del estudio como prólogo de Prosas profanas en su edición aumentada. Se comprende por qué-en los años venideros-las relaciones entre ambos escritores fuesen más bien frías y distantes. Muerto Darío, vuelve Rodó a ocuparse de él en un artículo generoso; 67 pero sus páginas más altas sobre la poesía dariana, las que revelan una integral comprensión de ese arte tan mal entendido en sus días, son las de I899. Por eso constituyen el fundamento de la crítica que, en este siglo, revelará los verdaderos alcances de la imaginación creadora de Rubén Darío.

\section{Universidad de Michigan}

JUAN LOVELUCK

64 Idem., ibid.

65 Ibidem, p. 46.

66 Rodó, Obras completas, p. 1293.

[* Podría agregarse que la "cabeza" de Rodó por Darío (Mundial Magazine, París, enero de 1912, vol. II, No. 9, p. 233), también es lacónica; empero el propio Rodó facilitó la fotografía para su dibujo de Vázquez Díaz, p. 232.]

67 "En la muerte de Rubén Dario", aparecido en el homenaje de Nosotros, Buenos Aires, 1916, y reproducido en las Obras completas, edición y tomo citados, pp. 998-999. 
